\title{
Preserving postharvest storage quality of fresh-cut cactus pears by using different bio-materials
}

\author{
Ibrahim Kahramanoğlu ${ }^{* *}$, Serhat Usanmaz ${ }^{1}$, Volkan Okatan² and Chunpeng Wan ${ }^{3}$
}

\begin{abstract}
Background: Cactus pear (Opuntia ficus-indica (L.) Miller) is an important food source for human beings but its consumption and marketability are limited due to the presence of spines and glochids on the fruit surface. Freshcut, ready-to-eat cactus pears have higher preference than the whole fruits. However, fresh-cut fruits have tissue wounding and quick deterioration, which decrease the marketability of the products. Therefore, present study was aimed to improve the storage quality of ready-to-eat cactus pears with the application of environmentally friendly bio-materials.
\end{abstract}

Methods: Fruits of present study were hand collected by a traditional way from a farm located in Yayla village of Northern Cyprus. Fruits were then peeled to prepare fresh-cut prickly pears for further experiments. Fruit peeling was carried out in three steps: (i) slicing off and discarding the both ends of the prickly pears, (ii) making one long vertical slice down the body, and (iii) peeling back the skin by sliping our finger into the slice and preparing a peeled prickly pear without skin. The six treatments of present study are: (1) control_-dipping the fruits into distilled water, (2) covering the fruits with Vitis vinifera leaves, (3) dipping the fruits into jelly, (4) dipping the fruits into Aloe vera gel, (5) dipping the fruits into Portulaca oleracea extract and (6) dipping the fruits into cactus gel. Totally 108 fruits (replications) were used for each treatment and 18 fruits from each treatment were selected for quality analysis with 3 -days interval $(3,6$, $9,12,15$ and 18 days). Fruits of each treatment ( 6 from same treatment) were placed into an open plastic box (dimensions: $20 * 13 * 5 \mathrm{~cm}$; material: PET) and was covered with a stretch film (LLDPE, $10 \mu \mathrm{m}$ ) for storage. The fruit boxes were stored at storage rooms adjusted to $5 \pm 1{ }^{\circ} \mathrm{C}$ and $55 \pm 5 \%$ relative humidity.

Results: Results showed that, all treatments have varying positive effects on the prevention of weight loss. Among them, the highest positive effect was received from $A$. vera gel treatment $(0.98 \%)$, and is followed by cactus gel $(1.15 \%), V$. vinifera leaf $(1.39 \%)$ and jelly (1.61\%) at the end of the experiments (18 days). A. vera gel and cactus gel were also found to have highest influence on the prevention of off-odor and decay incidence; and to protect the sensory and visual quality of the ready-to-eat cactus pears.

Conclusions: Results suggested that the postharvest storage duration of ready-to-eat cactus pears might be extended from 9 to 15 days with the use of Aloe vera gel or cactus gel.

Keywords: Weight loss, Decay, Aloe vera gel, Portulaca oleraceae extract, Vitis vinifera leaf, Cactus gel, Jelly

*Correspondence: ikahramanoglu@eul.edu.tr

1 European University of Lefke, via Mersin 10, Gemikonağı, Northern Cyprus, Turkey

Full list of author information is available at the end of the article

\section{Background}

Cactus pear (Opuntia ficus-indica (L.) Miller) is an important food source for human beings and is appreciated for its flavor and juiciness (Piga et al. 2000; Cefola et al. 2014), while plant parts are extremely useful for 
livestock forage in terms of drought tolerance and high biomass generation per unit of water (Márquez-Berber et al. 2012). The demand for the cactus fruit is increasing mainly because of the reported nutritional and functional significance (Tesoriere et al. 2004). The chemical composition of cactus pear fruit is reported to be similar with papaya, nectarine and oranges with about $85 \%$ water content and $10-15 \%$ carbohydrates. It is also an important source of ascorbic acid (25-30 mg $100 \mathrm{~g}^{-1}$ ) (Cantwell 1995). Cactus pears are non-climacteric and have very low ethylene production rate after harvest (Amaya-Cruz et al. 2019). Cactus pears are very sensitive to marketing conditions $\left(20{ }^{\circ} \mathrm{C}, 60-70 \%\right.$ R.H $)$ and have a few days of shelf life due to decay and weight loss; and the harvest time has significant influence on the chemical composition of the prickly pear fruits (Juhaimi et al. 2020). Cold storage is an important way of postharvest quality preservation for fresh fruits, but it is known that temperatures below $9-10{ }^{\circ} \mathrm{C}$ increases the susceptibility of cactus fruits to chilling injury (Granata and Sidoti 2002). Film packaging, controlled atmosphere $\left(2 \% \mathrm{O}_{2}\right.$ and $\left.2-5 \% \mathrm{CO}_{2}\right)$, modified atmosphere packaging, cauterization process and hot water treatment are reported to extend postharvest life of cactus pears (Ochoa-Velasco and Guerrero-Beltrán 2016; Hahn-Schlam et al. 2019).

Presence of spines and glochids on the fruit surface reduces the commercialization of the cactus fruits (Cefola et al. 2014). Due to the hassle of peeling the cactus fruits, ready-to-eat (fresh-cut) cactus fruits have higher demand in the market than the whole fruits (Timpanaro and Foti 2014). Peeling causes tissue wounds and accelerates fruit deterioration and discoloration (Goldman et al. 2004). Discoloration is an important postharvest problem for fresh-cut cactus pears which is caused by oxidation of the phenolic compounds catalyzed by the enzymatic actions of polyphenoloxidase (PPO). This also leads fruits to have off-flavors and causes losses in nutritional quality (Whitaker and Lee 1995; Goldman et al. 2004). There is very little published information about the postharvest storage quality of ready-to-eat (RTE) cactus pears. Passive modified atmosphere (Piga et al. 2003; Allegra et al. 2016) and cold storage at $2-4{ }^{\circ} \mathrm{C}$ (Añorve Morga et al. 2006) were reported to preserve postharvest storage quality of RTE cactus pears until about 9 and 12 days, respectively. Food scientists pay attention on the studies for developing new technologies to improve postharvest quality of fresh-cut fruits to meet consumer preferences (Cefola et al. 2014). Chemical treatments, surface coatings, calcium salt applications, modified atmosphere packaging and gamma radiation are the most known approaches for postharvest quality retention (Troyo and Acedo 2019). Chemicals, i.e. fungicides, which are widely used throughout the world for the preservation of the postharvest quality of fresh produce, began to lose their acceptability due to their possible negative effects on human health and environment (Sharma et al. 2009). Current trend in postharvest research is the use of bio-materials (Silvestre et al. 2011; Kahramanoglu 2020) i.e. chitosan (Tesfahun 2018) and Aloe vera gel (Anjum et al. 2020; Kahramanoğlu et al. 2019), essential oils (Kahramanoglu 2019), plant extracts (Chen et al. 2019), acids (Jiang et al. 2015), calcium salts (Zudaire et al. 2019) and edible coatings (Troyo and Acedo 2019). In one of the studies with fresh-cut fruits, Benítez et al. (2015) evaluated the effects of very different treatments ( $A$. vera, chitosan and sodium alginate) on the shelf life quality of fresh-cut kiwifruit. In the mentioned study, researchers noted that the sodium alginate, $A$. vera and chitosan act as a gas barrier and reduce the respiration rate of the fruits. The $A$. vera treatment was noted to maintain fruit textural and biochemical quality. On the other hand, it was noted that the microbial decay can be controlled by the application of $A$. vera and chitosan, where on the contrary sodium alginate treatment increased the microorganism counts. The effects of these treatments were reported to have different effects on the quality parameters and the highest overall quality was noted from the $A$. vera coatings. Cactus pears are also high in soluble sugar and low in acidity which makes them highly susceptible to microbial spoilage. In line with the background information, current study was conducted to test the storability of fresh-cut peeled cactus pears treated with different bio-materials: A. vera gel, Portulaca oleraceae extract, Vitis vinifera leaf, cactus gel and jelly. Five different bio-materials were selected in the present study to have a broad range of results and to increase the chances of success in postharvest storability of fresh-cut cactus pears.

\section{Materials and methods Materials}

Cactus fruits (Opuntia ficus-indica (L.) Miller) of present study were hand-collected from a local farm located in Yayla village of Northern Cyprus. Traditional, homemade tool called "coppo" was used to harvest fruits carefully. A $500 \mathrm{ml}$ plastic bottle was cut from mid-point and tied on a long stick. On 4th of August 2019, ripe yellowish red fruits were harvested by using coppo (Fig. 1.a.). The tool was dressed on the fruit, and the stick was turned by hand to twist of the fruit from the plant. The test materials of present study are: (1) control-dipping fruits into distilled water, (2) Vitis vinifera leaf-hand collected from local orchard with cv. 'Sultani', (3) jelly-purchased from a local shop with a brand of "Jello", (4) Aloe vera gel-collected from Yayla village, (5) Portulaca oleraceae extract-collected from Yayla village and (6) cactus gel-collected from the same plants of the fruit samples. 


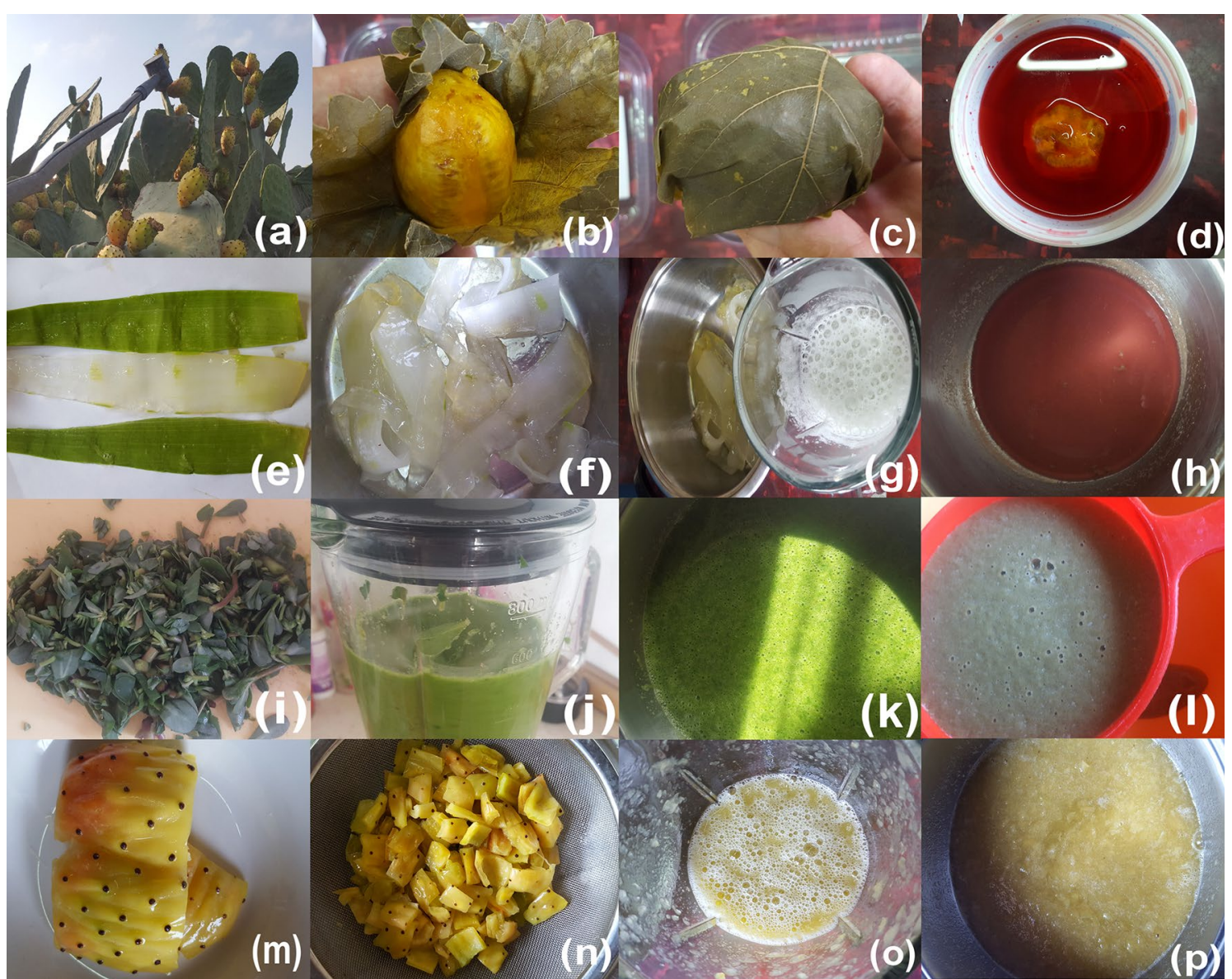

Fig. 1 Materials and methods of the experiments: $\mathbf{a}$ a view from harvesting cactus pears with traditional coppo; $\mathbf{b}, \mathbf{c}$ covering of fresh-cut cactus pears with Vitis vinifera leaves; $\mathbf{d}$ dipping fresh-cut cactus pears into jelly; $\mathbf{e}-\mathbf{h}$ preparation of the Aloe vera gel; $\mathbf{i}-\mathbf{I}$ preparation of Portulaca oleraceae extract; and $\mathbf{m}-\mathbf{p}$ preparation of cactus gel

\section{Methods}

After harvest, fruits were immediately brought to laboratory, selected to eliminate unripe and damaged fruits, and then professional workers peeled the fruits carefully. The fresh-cut fruits of present study were prepared by peeling the fruit skin. The peeling was performed in three steps: (i) slicing off and discarding the both ends of the prickly pears, (ii) making one long vertical slice down the body, and (iii) peeling back the skin by sliping our finger into the slice and preparing a peeled prickly pear without skin. Experimental studies were conducted with six treatments, which was listed above. Studies were planned to continue for 18 days and quality parameters of the fruits were analyzed with 3-day interval $(3,6,9$, 12,15 and 18 days). 108 fruits (replications) were used for each of the six treatments (listed above) and 18 fruits from each treatment were selected for quality analysis (18 fruits * 6 measurement point $=108$ fruits).After peeling, fruits were subjected to the treatments listed above. The descriptions of the treatments are:
1. First treatment was control. For this treatment, the fruits were dipped into distilled water at $24 \pm 1{ }^{\circ} \mathrm{C}$ for $10 \mathrm{~s}$ and then air dried for $30 \mathrm{~min}$ and then moved to storage conditions.

2. The second treatment was covering the fruits with Vitis vinifera leaf. The fruits were dipped into distilled water for $10 \mathrm{~s}$ as in control treatment, air dried for $30 \mathrm{~min}$ and then covered with Vitis vinifera leaves by using 2 leaves for each fruit (Fig. 1b, c) and moved to storage conditions.

3. The third treatment was jelly. The ingredients of jelly are edible gelatin, sugar, citric acid, natural or natural identical color and flavor. The jelly material was prepared according to the instructions. Totally $80 \mathrm{~g}$ of jelly was dissolved in $560 \mathrm{ml}$ of warm water and after $20 \mathrm{~min}$, it was transferred into freezer adjusted at $4{ }^{\circ} \mathrm{C}$ in cold storage. The duration required for freezing is about $3 \mathrm{~h}$. Therefore, it was kept $2 \mathrm{~h}$ in cold room and then transferred to ambient conditions and fresh-cut cactus pears were dipped into the half-fro- 
zen jelly for $10 \mathrm{~s}$ (Fig. 1d). Thus the fruits were taken out and transferred to the storage conditions.

4. The fourth treatment of the experiments is Aloe vera gel. Firstly, the leaves were harvested and the outer leaf rind was removed. The Aloe gel lying underneath was ground in a blender and the resulting mixture was filtered to remove fibers. The liquid was then pasteurized at $70{ }^{\circ} \mathrm{C}$ for $45 \mathrm{~m}$ (Fig. $1 \mathrm{e}-\mathrm{h}$ ). Hereafter, the resulting gel was cooled immediately and ready to use. Then, $10 \%$ of gel was used in the present study by dissolving it in distilled water in a ratio of 1:9 (w/v). Fruits were dipped into the solution and kept $10 \mathrm{~s}$. Next, air dried for $30 \mathrm{~min}$ and transferred to storage conditions.

5. The fifth treatment of the experiments was Portulaca oleraceae extracts. After collecting the plants, the above ground plant parts were chopped into small particles $(<2 \mathrm{~cm})$ and ground in a blender. Herein, the mixture was filtered and resulting solution was dissolved in distilled water in a ratio of $1: 1(\mathrm{w} / \mathrm{v})$. The liquid was then pasteurized at $70{ }^{\circ} \mathrm{C}$ for $45 \mathrm{~m}$ (Fig. 1i-l). Same procedure was used for the application and storage as in Aloe vera gel.

6. The final treatment of the present study is the cactus gel. The peel of the fruits of present study was used for the preparation of the cactus gel. The spines and glochids of the peels were removed carefully and the resulting material was chopped into small particles $(<2 \mathrm{~cm})$ and ground in a blender. Next, the mixture was filtered and resulting solution was dissolved in distilled water in a ratio of $1: 1(\mathrm{w} / \mathrm{v})$. The liquid was then pasteurized at $70{ }^{\circ} \mathrm{C}$ for $45 \mathrm{~m}$ (Fig. $1 \mathrm{~m}-\mathrm{p}$ ).

Storage condition for all treatments is: covering with stretch film (LLDPE, $10 \mu \mathrm{m}$ ) and keeping at $5 \pm 1{ }^{\circ} \mathrm{C}$. After dipping the fruits into mentioned solutions, fruits were air dried for $30 \mathrm{~min}$ (except jelly treatment) and then 6 fruits (from same treatment) were placed into an open plastic box (dimensions: $20 * 13 * 5 \mathrm{~cm}$; material: PET) and it was sealed up with a stretch film to provide a passive atmospheric packaging. Finally, the fresh-cut fruit boxes were immediately transferred to the storage rooms $\left(6 \mathrm{~m}^{*} 3 \mathrm{~m} * 3 \mathrm{~m}\right)$ adjusted to $5 \pm 1{ }^{\circ} \mathrm{C}$ and $55 \pm 5 \%$ relative humidity.

At the mentioned measurement points $(3,6,9$, 12, 15 and 18 days), 18 fruits from each treatment were taken out from storage rooms to measure quality parameters. First of all, fruit weight was measured with a digital scale sensitive to $\pm 0.01 \mathrm{~g}$ and weight loss was calculated for each replication by using the initial weight data. SSC (\% Brix) was measured with a hand refractometer (REF 103/Index Instruments Ltd.).
Hereafter, the overall sensory quality of the fresh-cut prickly pear fruits during the storage was then assessed by a panel of six trained person ( 3 women and 3 men; aged from 22 to 67 years). The sensory evaluation was performed according to the taste, aroma, texture and visual quality of the fruits. The nine-point scale of Aguayo et al. (2014) was used to determine sensory quality. This scale simply described as, $1=$ extremely poor (dislike), $2=$ dislike very much, $3=$ dislike moderately (poor), $4=$ dislike slightly, $5=$ limit of acceptability (neither like nor dislike), $6=$ like slightly, $7=$ like moderately (good), $8=$ like very much and $9=$ like extremely (excellent).

The severity of off-odor during the storage was determined with the Odor Index (OI) according to the 0-4 scale. The description of the scale is as 0 represents excellent fruits with no off-odor; 1 equals to slight off-odor; 2 represents moderate off-odor; 3 used for moderately severe off-odor; and 4 represents severe offodor. The OI index was then calculated using the following formula: OI index $=\left\{\sum[\right.$ (OI scale $) \times($ number of fruit at that OI $)]\} /(4 \times$ total number of fruit in each treatment). The fruits with an OI index of 0.4 or higher were considered as unacceptable for consumers.

Decay Incidence (DI) was observed according to the four-point scale formula of Cao et al. (2011). All fruits of each replication were visually evaluated according to the scale where 0 referred no decay, 1 equaled to slight decay $(\leq 25 \%), 2$ mentioned moderate decay $(25 \%<50 \%)$ and 3 referred severe decay $(>50 \%)$. After scoring the fruits according to above given scale, following formula was used to calculate Decay Incidence. $\mathrm{DI}=\{[(1 \times \mathrm{N} 1)+(2 \times \mathrm{N} 2)+(3 \times \mathrm{N} 3)] \times 100 /(3 \times \mathrm{N})\}$. In this formula, $\mathrm{N}$ represents the total number of fruit measured and N1, N2 and N3 were used to indicate the numbers of fruit showing the different severities of decay.

Visual appearance of the fruits was determined according to the 1-5 scale of Amodio et al. (2007). The description of the scale is as 5: Excellent, no defect; 4: good, minor effect; 3: fair, moderate defect (limit of marketability); 2: poor, major defect (limit of edibility); and 1: inedible. The arithmetic mean of the scores was used to calculate the overall score of each treatment.

\section{Data analysis}

The effects of above mentioned six treatments at the given storage durations were determined by subjecting the raw data (Additional file 1) separately to the analysis of variance (ANOVA). Furthermore, separation of means was carried out with Tukey's Honestly 
Significant Difference (HSD) test at $\mathrm{P}=0.05$. SPSS 22.0 was used in present study to perform statistical analysis.

\section{Results}

\section{Effects on weight loss}

Effects of test materials on the weight loss of readyto-eat cactus pears are given in Fig. 1. It is clear from the figure that the untreated control fruits had higher weight loss $(0.78 \%)$ even in 3 days of storage than the others $(0.13-0.50 \%)$. Among the test materials, cactus gel and jelly treatment found to have highest effect in the first 3 days of storage and fruits had very low weight loss $(0.13-0.14 \%)$. Covering fruits with $V$. vinifera leaves and A. vera gel treatment found to have third and fourth highest influence on the weight loss prevention with a rate of $0.36 \%$ for both (Fig. 2). During ongoing storage, the positive effect of cactus gel and jelly decreased and the highest positive effect was determined from A. vera gel. However, all of the biomaterials were found to effective when comparing with control treatment. At the end of the experiments (18 days of storage), the highest weight loss was measured from control treatment $(2.83 \%)$ and was followed by $P$. oleraceae extracts $(2.31 \%)$. No statistical difference was determined among these two treatments. On the other hand, the lowest weight loss (thus the highest influence) was obtained from the $A$. vera gel treatment with only $0.98 \%$ weight loss. This treatment was followed by cactus gel (1.15\%), V. vinifera leaf $(1.39 \%)$ and jelly (1.61\%) and no statistical difference was found among these three treatments.

\section{Effects on soluble solids concentration}

At the day of harvest, the soluble solids concentration (SSC) of the cactus pears was measured as $11.84 \%$. During the first 3 days of storage, the SSC content of the all samples showed slight increase (Fig. 3.). It was measured as between $11.91 \%$ and $12.10 \%$ at 3 days after storage and began to show a slight decrease afterwards. It was measured as between $11.89 \%$ and $12.06 \%$ at 6 days after storage. Until the measurements done at 9th day of storage, there was not statistically significant difference among the treatments. Hereafter, the untreated control fruits found to have lower SSC as compared with treated fruits. At the end of the experiments (18 DAS), the highest SSC was noted from cactus gel treatment with $10.83 \%$, as was followed by $A$. vera gel and P. oleraceae extract with $10.17 \%$, jelly $(10.03 \%)$ and $V$. vinifera leaf (9.91\%). The SSC values of these four treatments were found to have no significant difference from each other. However, these values were less than the SSC of the fruits treated with cactus gel and slightly higher than the control fruits $(9.65 \%)$. Results showed

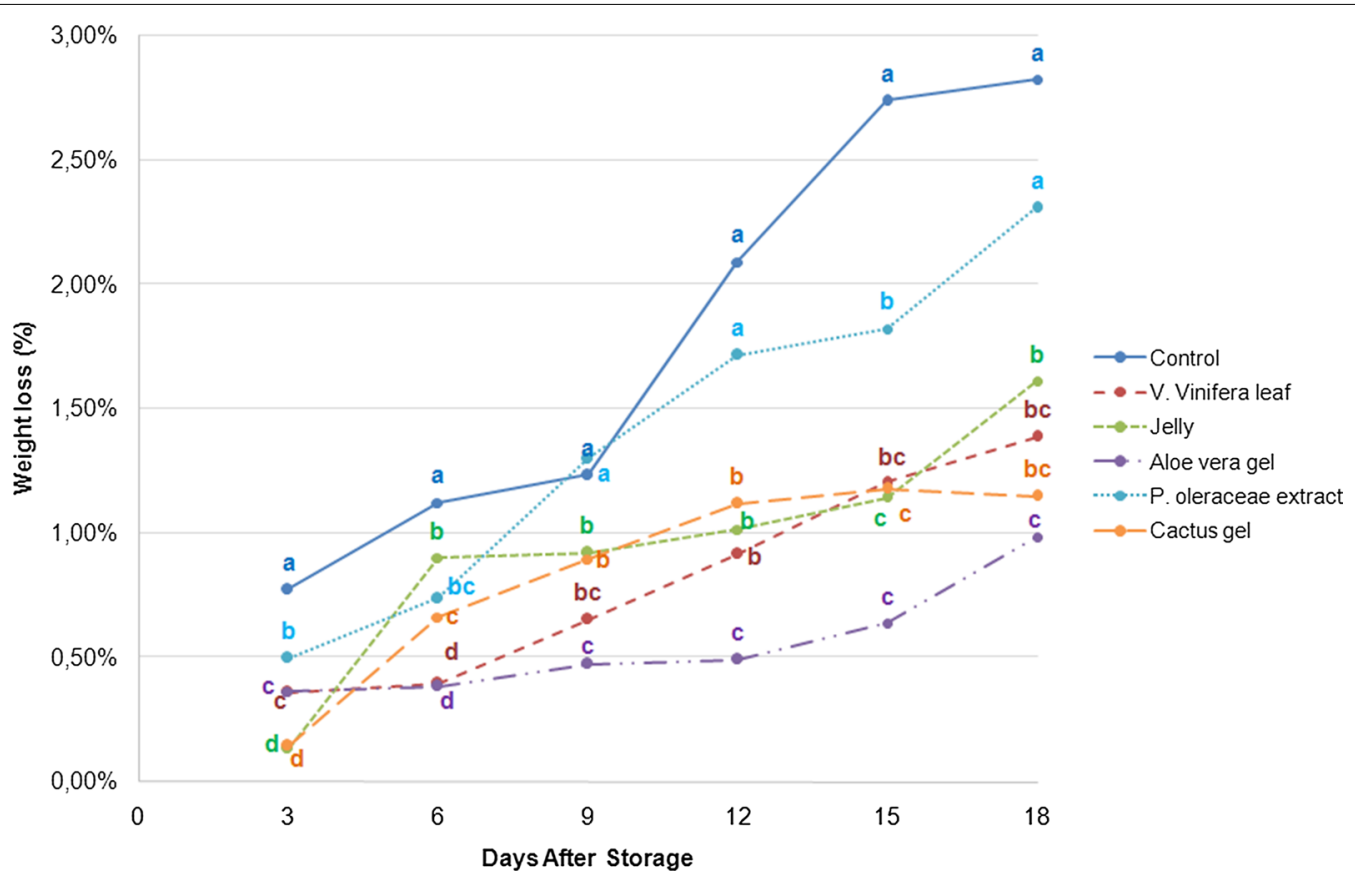

Fig. 2 Effects of different bio-materials on the weight loss of ready-to-eat cactus pears during 18 days of storage. Values followed by the same letter or letters at the same day of storage duration are not significantly different according to Tukey's HSD at $P=0.05$ 


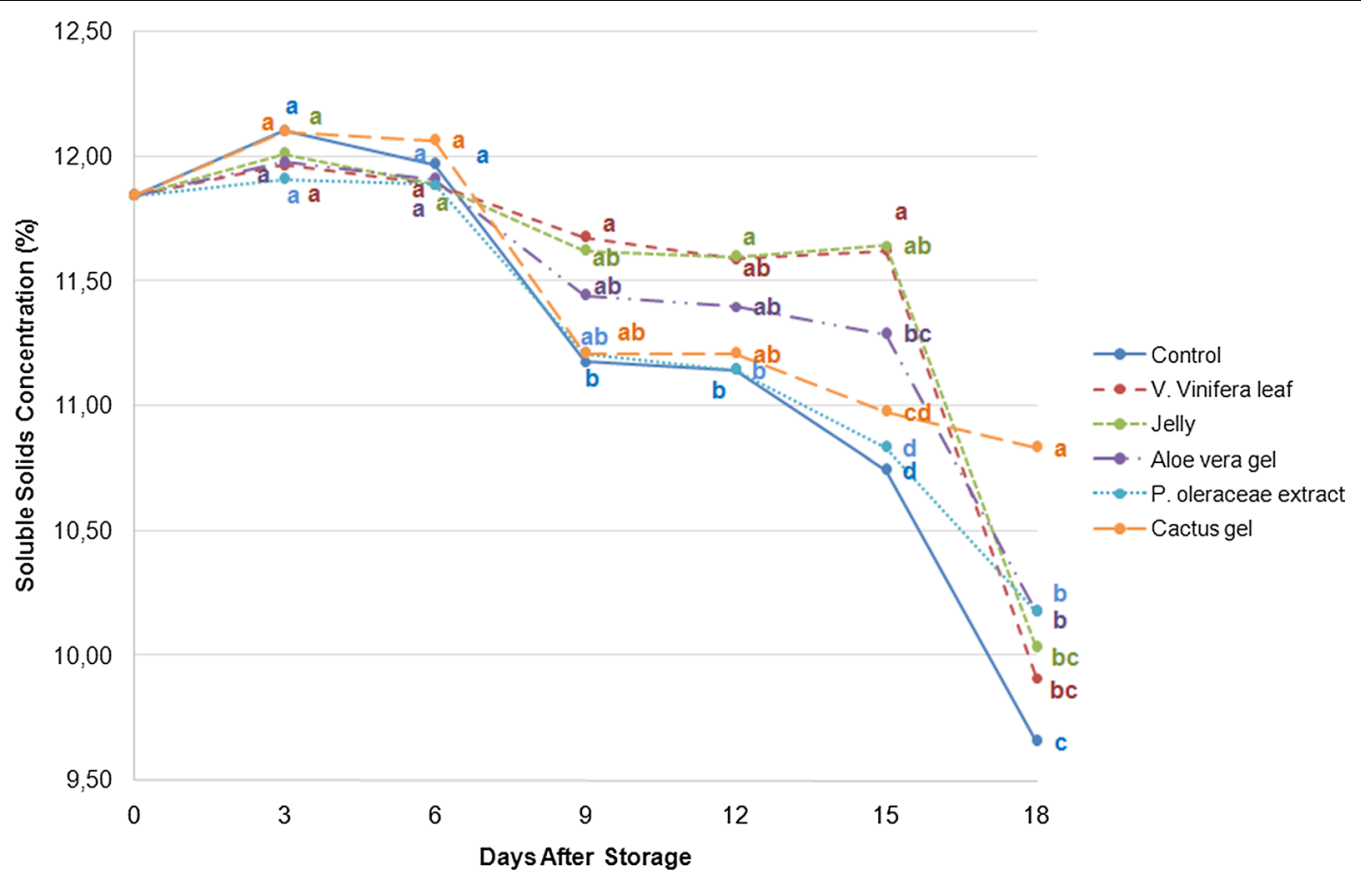

Fig. 3 Effects of different bio-materials on the soluble solids concentration of ready-to-eat cactus pears during 18 days of storage. Values followed by the same letter or letters at the same day of storage duration are not significantly different according to Tukey's HSD at P $=0.05$

that all treatments have considerable and varying effect on the prevention of SSC as in weight loss.
Effects on visual appearance

Along with the weight loss and SSC results, visual appearance is at utmost importance for the postharvest

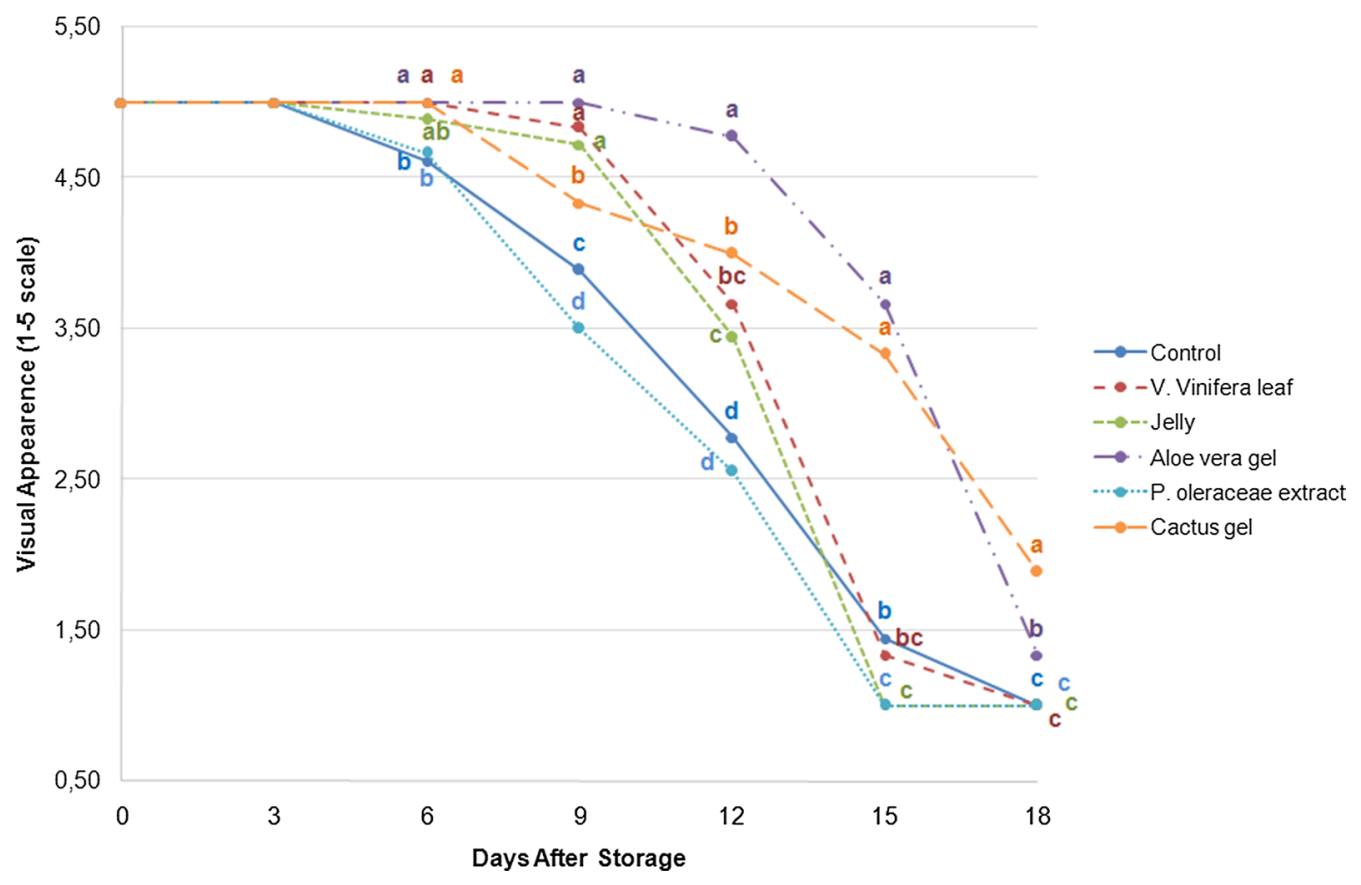

Fig. 4 Effects of different bio-materials on the visual appearence of ready-to-eat cactus pears during 18 days of storage. Values followed by the same letter or letters at the same day of storage duration are not significantly different according to Tukey's HSD at P $=0.05$ 
quality of fresh and fresh-cut produce. While food safety issues are of great importance for consumers, visual appearance is still the first impression and highly influences the choice of consumers. Results of present study are in accordance with those results where the $A$. vera gel was found to have second highest influence on the prevention of visual quality after cactus gel (Fig. 4).

Fruits treated with $P$. oleraceae extract were found to have fewer score, even than the control treatment during the storage. Similarly, fruits treated with jelly found to have very low visual quality scores. According to the results obtained, all fruits, even the untreated control fruits had acceptable marketability quality for 9 days of storage. Twelve days after storage, fruits treated with $P$. oleraceae extract (2.55) and control (2.78) found to have lower quality scores than the limit of marketability. Visual quality scores of fruits treated with jelly and $V$. vinifera leaves was higher at 12 DAS, but decreased to 1.00 and 1.33 at 15 DAS, respectively. The fruits treated with $A$. vera gel and cactus gel had acceptable visual quality for

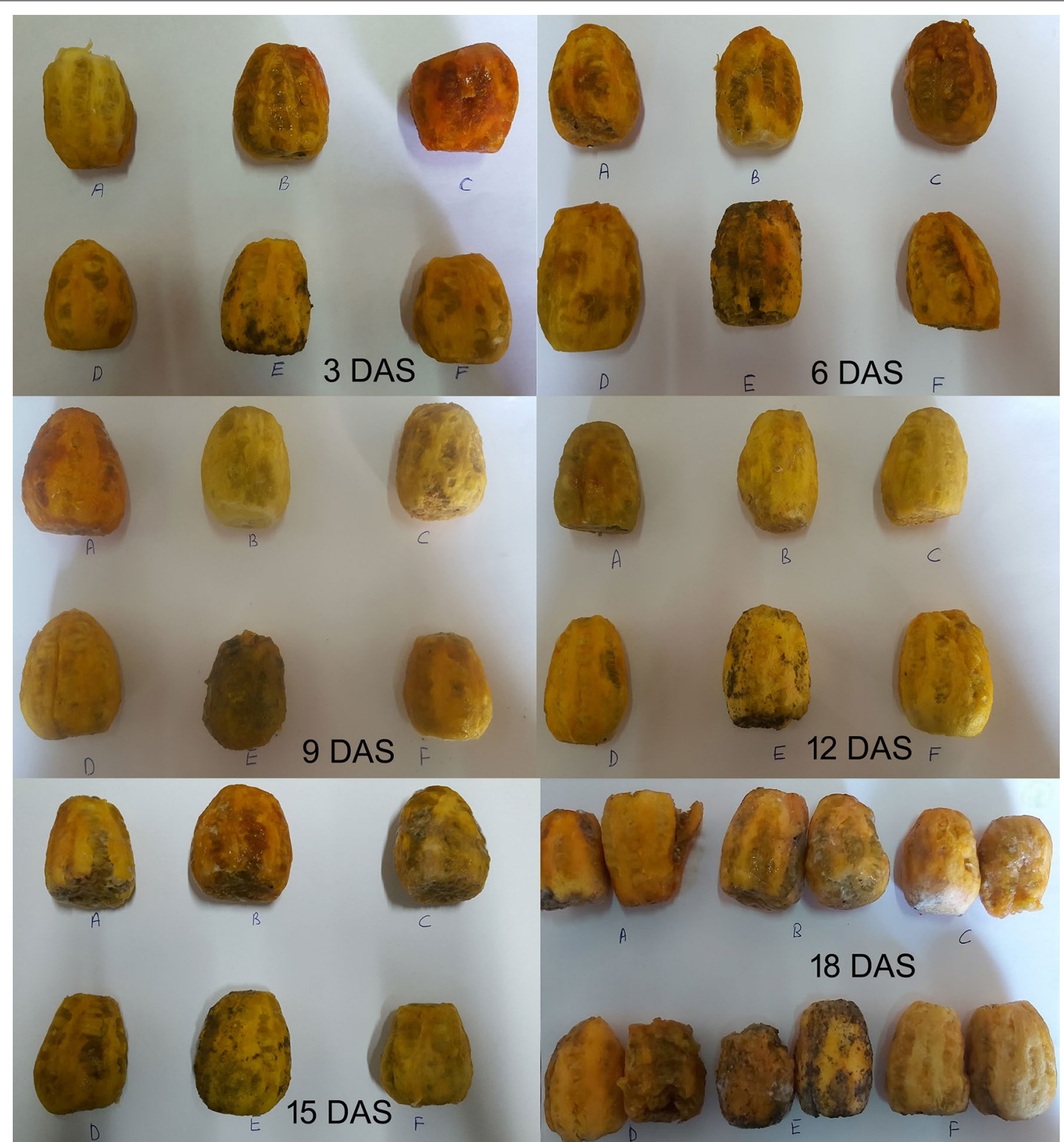

Fig. 5 Visual appearance of cactus fruits during storage [DAS: Days After Storage; a Control; b Coverage with Vitis vinifera leaves; c Jelly treatment; $\mathbf{d}$ Aloe vera gel; e Portulaca oleraceae extract; and $\mathbf{f}$ cactus gel] 
marketability with the scores of 3.67 and 3.33, 15 days after storage. Hereafter, at the 18 DAS, fruits of all treatments found to have inedible fruits with very low visual quality scores (1.00-1.89). The visual appearance of the cactus pears can be seen from the Fig. 5 .

\section{Effects on off-odor}

The aroma of fresh and fresh-cut fruits and vegetables is an important quality attribute for consumer acceptability. Results of present study showed that the tested bio-materials have significant varying effect on the weight loss and on the off-odor too. Similar with the other results, fruits treated with $A$. vera gel and cactus gel found to have no off-odor in 6 days of storage. Nine days after storage, all treatments found to have off-odor (Fig. 6.). The highest off-odor scores were noted from the fruits treated with P. oleraceae extract and control with scores of 0.36 and 0.44 , respectively (very close or higher than acceptable limit $=0.40$ ). In terms of off-odor scores, fruits treated with $A$. vera gel, cactus gel, jelly and $V$. vinifera leaf have acceptable quality for 12 days of storage, but the offodor increase afterwards to a minimum score of 0.42 in 15 days of storage.

\section{Effects on microbial spoilage}

Results of present study also showed that all of the tested bio-materials (except P. oleraceae leaves) are effective in controlling decay. The reducing effect of $P$. oleraceae extracts on the weight loss and other quality parameters might also be associated with the reduced effect on the control of decay. At 9 days of storage, control fruits found to have $35.17 \%$ decay, while the decay at the fruits treated with $A$. vera gel was only $0.00 \%$ (Fig. 7.). Fruits treated with $A$. vera gel, V. vinifera leaves and cactus gel were found to have a decay score of $\leq 20.00 \%$ with the rates of $7.43 \%, 16.67 \%$ and $20.40 \%$, respectively. At the end of the experiments, $A$. vera gel was found to be the most effective material for preventing microbial spoilage.

\section{Effects on sensory quality}

One of the most important results of present study is about the sensory quality of the fresh-cut prickly pear fruits. The results about the sensory quality are in accordance with the visual quality and off-odor results. The sensory quality of the fresh-cut fruits began to decrease 6 days after the storage (Fig. 8.). According to the results obtained, the sensory quality of the fruits treated with $P$. oleraceae extracts and the control were found to decrease below the limit of acceptability (5) in 9 days of storage. Other treatments were found to have higher and acceptable sensory quality until the end of the 12th day of storage. Hereafter, the sensory quality of fruits in all

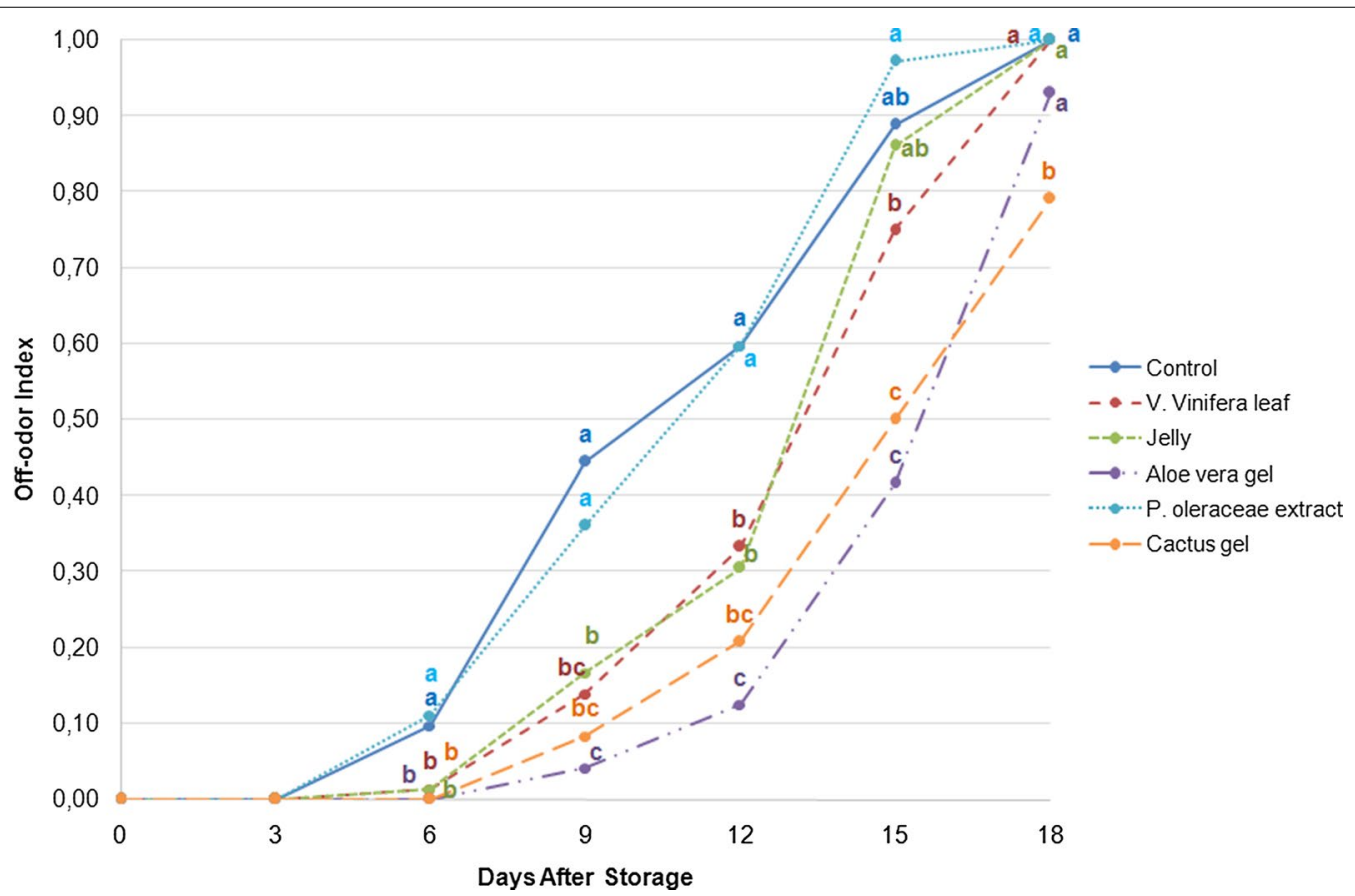

Fig. 6 Effects of different bio-materials on the off-odor of ready-to-eat cactus pears during 18 days of storage. Values followed by the same letter or letters at the same day of storage duration are not significantly different according to Tukey's HSD at $P=0.05$ 


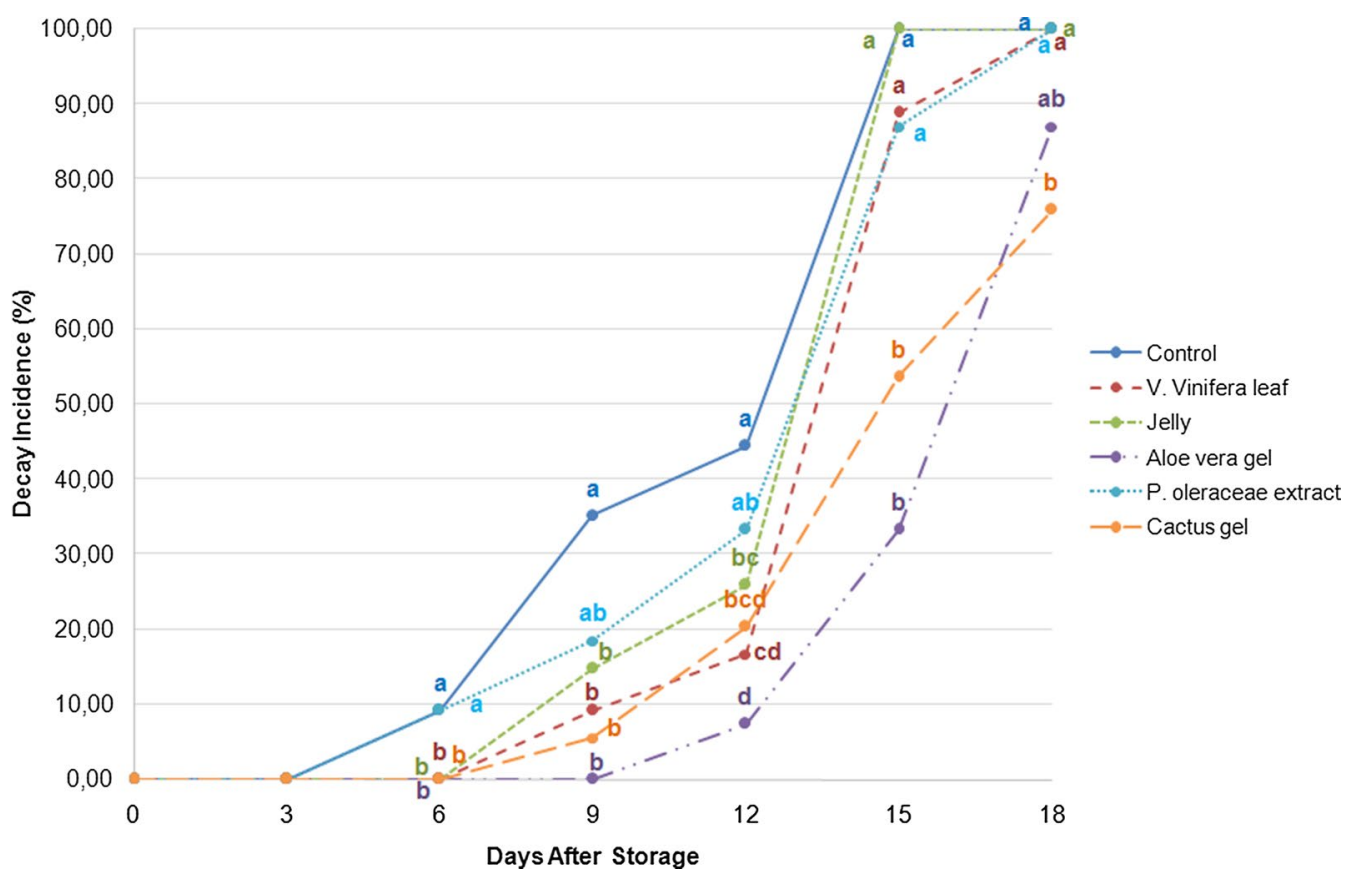

Fig. 7 Effects of different bio-materials on the decay incidence of ready-to-eat cactus pears during 18 days of storage. Values followed by the same letter or letters at the same day of storage duration are not significantly different according to Tukey's HSD at $\mathrm{P}=0.05$

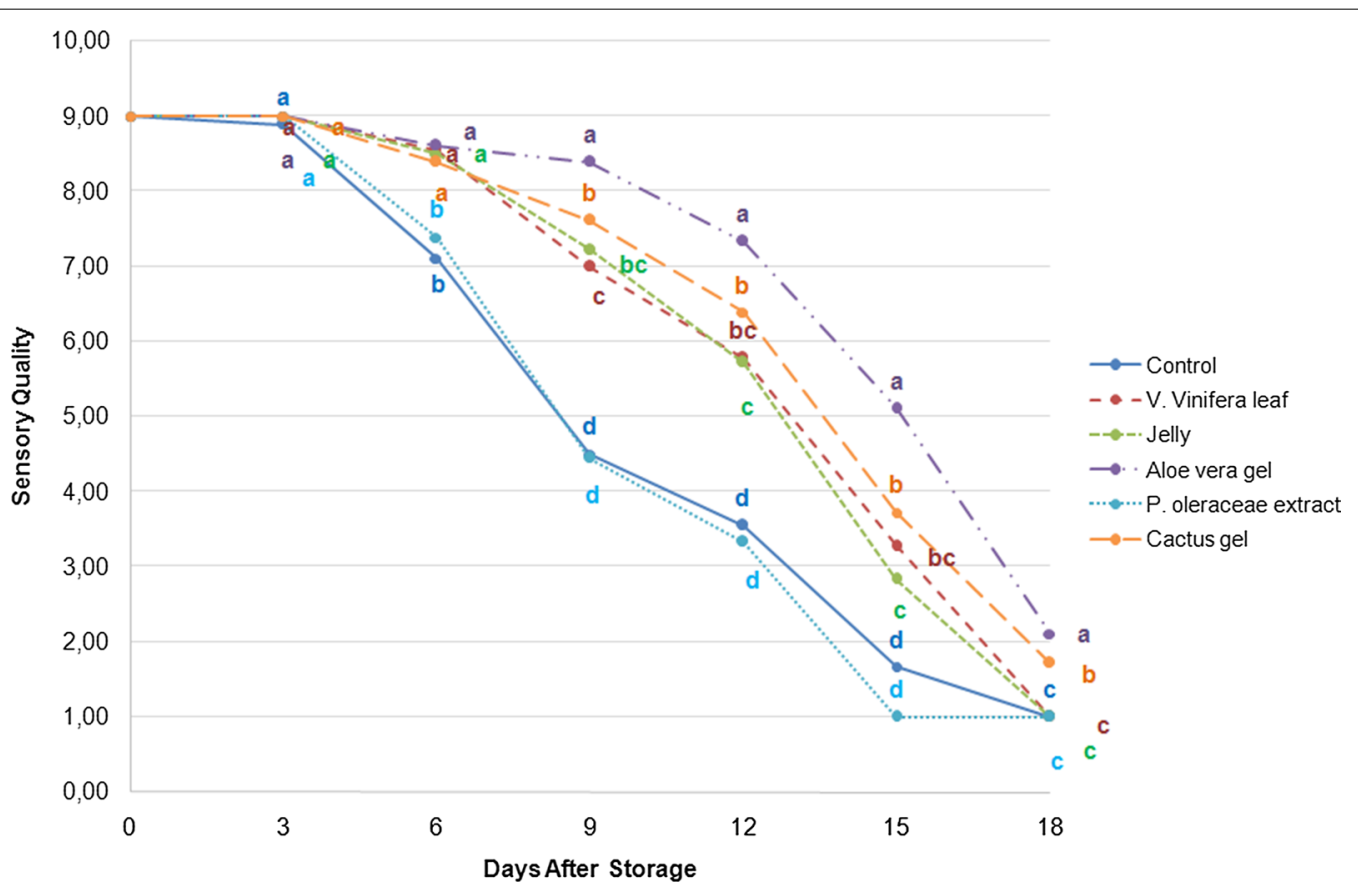

Fig. 8 Effects of different bio-materials on the sensory quality ready-to-eat cactus pears during 18 days of storage. Values followed by the same letter or letters at the same day of storage duration are not significantly different according to Tukey's HSD at P $=0.05$

treatments, except $A$. vera gel, decreased below the limit of acceptability. All of those results are in accordance with the other findings, which clearly indicate that the
A. vera gel treatment improve the postharvest storability of fresh-cut prickly pear fruits and help to keep fruits acceptability for 15 days of storage. 


\section{Discussions}

In this study, A. vera gel provided the highest efficacy in preventing weight loss and protecting visual and sensory quality of fresh-cut cactus pear fruits. Weight loss is mainly a cause of respiration (loss of carbon reserves) and transpiration (loss of water), and $A$. vera gel was highly cited by numerous studies to acts as a barrier, thereby restricting water transfer and prevents weight loss (Achipiz et al. 2013; Kator et al. 2018; Kahramanoglu et al. 2019). Previous studies demonstrated successful results for A. vera gel coatings for both fresh and freshcut fruits and vegetables, i.e.: pineapples (Adetunji et al., 2012), tomato (Kator et al. 2018), ready-to-eat pomegranate arils (Martínez-Romero et al. 2013), fresh-cut papaya fruits (Kuwar et al. 2015), fresh-cut oranges (Radi et al. 2017), fresh-cut apples (Song et al. 2013) and freshcut kiwifruits (Benítez et al. 2015). It is noted by those researchers that $A$. vera gel application provides a barrier to the produce and lower the respiration rate. According to Author's knowledge, there is not any published study about the use of $A$. vera gel for the fresh-cut cactus pears. The second highest effect on the prevention of weight loss at the ready-to-eat cactus pears was obtained from cactus gel. Previously, extracts from other parts of the cactus plants, mainly the cladodes, were tested on different fruits and found to be effective in preventing weight loss (Allegra et al. 2016; Gheribia et al. 2018). The third most successful treatment of present study was found to be covering the fruits with $V$. vinifera leaves. According to the Author's knowledge, it is first time to test $V$. vinifera leaves as a postharvest treatment. Grape leaves have wide use in Mediterranean countries as cooked with rice. Due to the high use of $V$. vinifera leaves in diet, many studies conducted about the health effects, antibacterial, antifungal, antiviral, antioxidant activities, and phenolic and volatile contents of leaves (Fernandes et al. 2013; Pintaća et al. 2019). Orhan et al. (2009) reported that $V$. vinifera leaves have antiviral and antioxidant activities which support their utilization in folk medicine. At the beginning of the experiments (3 DAS) jelly was one of the most effective materials for the prevention of weight loss, but its efficacy decreased in time and found to be the fourth effective material among the tested bio-materials. Gelatin (natural water soluble protein) based coatings were previously reported to be effective in preventing postharvest quality and weight loss (Mellinas et al. 2016; Ortiz-Zarama et al. 2016), but it was a first report for the jelly. The reduced effect of jelly in present study might be a cause of sugar in the jelly or the application method. Further studies by freezing the fresh-cut fruits in jelly would provide higher efficacy than the present methodology. Gol and Rao (2013) reported that 10\% gelatin coating reduces the weight loss at mango fruits and improves the postharvest quality. The final bio-material of present study was $P$. oleraceae extracts. $P$. oleracea is an annual herbaceous plant, distributed in many parts of the world (Zhou et al. 2015) and has been used as a traditional medicine against gastrointestinal diseases, headaches, some kind of inflammation, ulcer, sexual desire, eruptions of blood, burning of the stomach, and etc. (Iranshahy et al. 2017). The un-expected low efficacy of the $P$. oleraceae extracts might be a cause of the negative effects of extracts on the decay and future studies are necessary with different preparation methods and/or combination with some other bio-materials.

Additional to the prevention of weight loss, $A$. vera gel was also found to maintain fruit SSC. This is in agreement with the previous studies which reported that $A$. vera gel reduces the speed of the changes in soluble solids concentration at different fruits and vegetables, i.e. strawberry (Sogvar et al. 2016), tomato (Chrysargyris et al. 2016), fresh-cut papaya fruits (Kuwar et al. 2015) and fresh-cut oranges (Radi et al. 2017). Parven et al. (2020) reported that the coating of papaya fruits with $A$. vera gel provides favorable conditions for the prevention of fruit SSC.

There is limited available information in the published literature about the impacts of tested bio-materials on visual quality. Only $A$. vera gel was noted previously to have positive impact on visual quality (Mohebbi et al. 2014; Sophia et al., 2015; Song et al. 2013) which are in accordance with the results of present study. In a very recent study by Parven et al. (2020), A. vera gel coating was reported to delay colour development during storage which improved the visual quality of the papaya fruits. Ali et al. (2019) reported that the lotus root slices coated with $A$. vera gel have better overall visual quality as compared with the uncoated control fruits during storage. They reported that the uncoated control slices lost marketability in 4 days of stoage, slices coated with $A$. vera gel had markedly higher visual quality until 8 days of storage. Similar results were previously noted by Supapvanich et al. (2016) and it was suggested that it could possibly due to reduced enzymatic browning of fruit surface.

Rather than visual quality, the development of off flavor was also an important characteristic in present study. The aroma of fresh and fresh-cut fruits and vegetables is an important quality attribute for consumer acceptability (Cefola et al. 2014). Composition of the volatile compounds released from the produce determines the aroma of the produce. Wounding of tissues accelerates respiration and removes natural diffusion barriers, with associated increases in rates of other biochemical reactions resulting with changes in color, texture, odor, flavor and nutritional quality. Lack of oxygen in the surrounding atmosphere also causes anaerobic 
respiration which results in off-odors (Forney, 2016). Although the information about the biosynthesis mechanisms is still limited, it is known that the postharvest practices significantly affect it (Defilippi et al. 2009). Previous studies suggested that the suppression of respiration plays an important influence on the prevention of off-odor on fresh produce (Dang et al. 2008). In agreement with this knowledge, results of present study showed that the bio-materials of present study have significant varying effect on the weight loss (estimated to have on respiration) and on the off-odor too. Similar with the other results, fruits treated with $A$. vera gel and cactus gel found to have no off-odor during the first 6 days of storage. Present results for A. vera gel are in accordance with the reports of Dang et al. (2008) who noted that the application of $A$. vera-based coatings reduce aroma volatile biosynthesis in the fruit pulp of mango. Finally, $A$. vera gel, $V$. vinifera leaves and cactus gel were found to have a decay score of $\leq 20.00 \%$ in present study. There is no published literature about the $V$. vinifera and cactus gel, whereas high potential of $A$. vera gel on the prevention of microbial spoilage was previously noted for other fruits and vegetables, i.e. tomato (Chrysargyris et al. 2016), citrus (Jhalegar et al. 2014), raspberry (Hassanpour et al. 2015), and readyto-eat pomegranate arils (Martínez-Romero et al. 2013).

Reduction of the microbial decay is indispensable for prolonging the safe storage of fresh-cut products (Li et al. 2018). The observed percentage of the decay incidence in present study suggested that the $A$. vera gel coating provides moderate to high control over the postharvest diseases. The positive effect of $A$. vera gel for the prevention of disease severity is not new, and the results of present study are in agreement with the findings of several studies (Martínez-Romero et al. 2006; Benítez et al. 2015; Kahramanoglu et al. 2019; Mendy et al. 2019; Rasouli et al. 2019; Parven et al. 2020). A. vera gel coating was previously noted to exhibit satisfactory inhibition of mycelial growth and spore germination (Mendy et al. 2019). Similarly, Ali et al. (2019) noted that the $A$. vera gel coating decreases the aerobic bacteria at the lotus root slices during storage.

Sensory quality of fresh-cut fruits and vegetables is most important characteristic influencing the consumer satisfaction (Ragaert et al. 2011). In this study, $A$. vera gel, cactus gel, $V$. vinifera leaf covering and jelly coating were all found to maintain sensory quality above the acceptable limit for 12 days; and the A. vera gel was effective for 15 days of storage. In the studies of Benítez et al. (2015) similar results were reported for $A$. vera gel coating for maintaining the sensory quality of the kiwifruits. Similarly, Martínez-Romero et al. (2006) suggested that the natural look sweet cherry fruits can be kept 16 days in cold room with the application of $A$. vera gel coating.

\section{Conclusions}

Results of present study suggested that the postharvest storage duration of the ready-to-eat cactus pears might be extended with the use of different bio-materials. The Aloe vera gel and cactus gel were found to be highly effective in protecting weight loss, sensory quality, visual quality, occurrence of microbial spoilage, development of off-odor and changes in soluble solids concentration. Results are also promising for jelly and $V$. vinifera leaves but further studies need to be undertaken especially about the application methodology.

\section{Supplementary information}

Supplementary information accompanies this paper at https://doi. org/10.1186/s43170-020-00008-5.

Additional file 1. Raw data, mean and standard deviation for all quality parameters.

\section{Acknowledgements}

Authors would like to send their thanks to the Tezer Kahramanoğlu (mum of the corresponding author) for her valuable helps during the preperation of fresh-cut cactus pears.

\section{Authors' contributions}

IK and SU conceptualized the study. All authors design the experiment. IK and SU performed the experiments and collected the data. IK and VO analyzed the data and prepared the figures. IK and CW were the major contributor in writing the manuscript. All authors read and approved the final manuscript.

Funding

Not applicable.

Availability of data and materials

All data generated or analysed during this study are included in this published article [and its additional information files].

Ethics approval and consent to participate

Not applicable.

Consent for publication

Not applicable.

Competing interests

Not applicable.

\section{Author details}

${ }^{1}$ European University of Lefke, via Mersin 10, Gemikonağı, Northern Cyprus, Turkey. ${ }^{2}$ Department of Horticulture, Faculty of Agriculture and Natural Sciences, Uşak University, Uşak, Turkey. ${ }^{3}$ Jiangxi Key Laboratory for Postharvest Technology and Nondestructive Testing of Fruits \& Vegetables/Collaborative Innovation Center of Postharvest Key Technology and Quality Safety of Fruits \& Vegetables in Jiangxi Province, College of Agronomy, Jiangxi Agricultural University, Nanchang 330045, China.

Received: 15 May 2020 Accepted: 30 June 2020

Published online: 09 July 2020 


\section{References}

Achipiz SM, Castillo AE, Mosquera SA, Hoyos JL, Navia DP. Efecto de Recubrimiento a Base de Almidón Sobre la maduracion de la Guayaba (Psidium guajava). Biotecnol en el Sect Agropecu y Agroind. 2013;2(2):92-101.

Adetunji CO, Fawole OB, Arowora KA, Nwaubani SI, Ajayi ES, Oloke JK Majolagbe OM, Ogundele BA, Aina JA, Adetunji JB. Effects of edible coatings from Aloe vera gel on quality and postharvest physiology of Ananas comosus (L.) fruit during ambient storage. Glob J Sci Front Res. 2012;12(5):39-43.

Aguayo E, Escalona V, Silveira AC, Artés F. Quality of tomato slices disinfected with ozonated water. Food Sci Technol Int. 2014;20(3):227-35.

Ali S, Khan AS, Anjum MA, Nawaz A, Naz S, Ejaz S, Hussain S. Aloe vera gel coating delays post-cut surface browning and maintains quality of cold stored lotus (Nelumbo nucifera Gaertn.) root slices. Sci Hortic. 2019. https ://doi.org/10.1016/j.scienta.2019.108612.

Allegra A, Inglese P, Sortino G, Settanni L, Todaro A, Liguori G. The influence of Opuntia ficus-indica mucilage edible coating on the quality of'Hayward'kiwifruit slices. Postharvest Biol Tech. 2016. https://doi. org/10.1016/j.postharvbio.2016.05.011.

Amaya-Cruz DM, Pérez-Ramírez IF, Delgado-García J, Mondragón-Jacobo C, Dector-Espinoza A, Reynoso-Camacho R. An integral profile of bioactive compounds and functional properties of prickly pear (Opuntia ficus indica L.) peel with different tonalities. Food Chem. 2019. https://doi. org/10.1016/j.foodchem.2018.11.031.

Amodio ML, Cabezas S, Rinaldi R, Colelli G. Implementation of rating scales for visual quality evaluation of various vegetable crops. In: Kader AA, Cantwell $M$, editors. Produce quality rating scales and color charts postharvest horticulture series no. 23, September 2004, revised May 2007 Davis CA-USA.

Anjum MA, Akram H, Zaidi M, Ali S. Effect of gum arabic and Aloe vera gel based edible coatings in combination with plant extracts on postharvest quality and storability of 'Gola'guava fruits. Sci Hortic. 2020. https://doi. org/10.1016/j.scienta.2020.109506.

Añorve Morga J, Aquino Bolaños EN, Mercado Silva E. Effect of storage temperature on quality of minimally processed cactus pear. Acta Hort. 2006 https://doi.org/10.17660/ActaHortic.2006.728.31.

Benítez S, Achaerandio I, Pujolà M, Sepulcre F. Aloe vera as an alternative to traditional edible coatings used in fresh-cut fruits: a case of study with kiwifruit slices. LWT. 2015. https://doi.org/10.1016/j.lwt.2014.11.036.

Cantwell M. Post-harvest Management of Fruits and Vegetable stems. In: Barbera G, Inglese P, Pimienta-Barrios E, editors. Agro-ecology, cultivation and uses ofcactus pear. FAO plant production and protection paper 132. Rome; 1995. p. 216.

Cao S, Zheng Y, Yang Z. Effect of 1-MCP treatment on nutritive and functional properties of loquat fruit during cold storage. N Z J Crop Hortic Sci. 2011. https://doi.org/10.1080/01140671.2010.526621.

Cefola M, Renna M, Pace B. Marketability of ready-to-eat cactus pear as affected by temperature and modified atmosphere. J Food Sci Technol. 2014. https://doi.org/10.1007/s13197-011-0470-5.

Chen J, Shen Y, Chen C, Wan C. Inhibition of key citrus postharvest fungal strains by plant extracts in vitro and in vivo: a review. Plants. 2019. https:// doi.org/10.3390/plants8020026.

Chrysargyris A, Nikou A, Tzortzakis N. Effectiveness of Aloe vera gel coating for maintaining tomato fruit quality. N Z J Crop Hort Sci. 2016. https://doi. org/10.1080/01140671.2016.1181661.

Dang KTH, Singh Z, Swinny EE. Edible coatings influence fruit ripening, quality, and aroma biosynthesis in mango fruit. J Agric Food Chem. 2008. https:// doi.org/10.1021/jf072208a.

Defilippi BG, Manríquez D, Luengwilai K, González-Agüero M. Chapter 1 Aroma volatiles: biosynthesis and mechanisms of modulation during fruit ripening. Adv Bot Res. 2009. https://doi.org/10.1016/s0065-2296(08)00801-X.

Fernandes F, Ramalhosa E, Pires P, Verdial J, Valentao P, Andrade P, Bento A, Pereira JA. Vitis vinifera leaves towards bioactivity. Ind Crops Prod. 2013. https://doi.org/10.1016/j.indcrop.2012.07.031.

Forney CF. Physiology and biochemistry of aroma and off-odors in freshcut products. Acta Hortic. 2016. https://doi.org/10.17660/ActaHortic .2016.1141.4.

Gheribia R, Puchotb L, Vergeb P, Jaoued-Grayaac N, Meznic M, Habibib Y, Khwaldia K. Development of plasticized edible films from Opuntia ficusindica mucilage: a comparative study of various polyol plasticizers. Carbohydr Polym. 2018. https://doi.org/10.1016/j.carbpol.2018.02.085.
Gol NB, Rao TVR. Influence of zein and gelatin coatings on the postharvest quality and shelf life extension of mango (Mangifera indica L.). Fruits. 2013. https://doi.org/10.1051/fruits/2014002.

Goldman G, Vinokur Y, Horev B, Lurie S, Rodov V, Liguori G. Fresh-cut products from cactus species. V International Postharvest Symposium. 2004;682:1961-6.

Granata G, Sidoti A. Survey of diseases discovered on Opuntia ficus-indica in producer countries. Acta Hortic. 2002. https://doi.org/10.17660/ActaH ortic.2002.581.24

Hahn-Schlam F, Valle-Guadarrama S, Jenkins T. Robotic cactus pear cryocauterization increases storage life. Postharvest Biol Technol. 2019. https:// doi.org/10.1016/j.postharvbio.2018.09.014

Hassanpour $\mathrm{H}$. Effect of Aloe vera gel coating on antioxidant capacity, antioxidant enzyme activities and decay in raspberry fruit. LWT. 2015. https:// doi.org/10.1016/j.lwt.2014.07.049

Iranshahy M, Javadi B, Iranshahi M, Jahanbakhsh SP, Mahyari S, Hassani SV, Karimi G. A review of traditional uses, phytochemistry and pharmacology of Portulaca oleracea L. J Ethnopharmacol. 2017. https://doi.org/10.1016/j. jep.2017.05.004

Jhalegar J, Sharma RR, Singh D. Antifungal efficacy of botanicals against major postharvest pathogens of Kinnow mandarin and their use to maintain postharvest quality. Fruits. 2014. https://doi.org/10.1051/fruits/2014012.

Jiang $L$, Jin $P$, Wang L, Yu X, Wang H, Zheng Y. Methyl jasmonate primes defense responses against Botrytis cinerea and reduces disease development in harvested table grapes. Sci Hortic. 2015. https://doi. org/10.1016/j.scienta.2015.06.015.

Juhaimi FA, Ghafoor K, Uslu N, Ahmed IAM, Babiker EE, Özcan MM, Fadimu GJ. The effect of harvest times on bioactive properties and fatty acid compositions of prickly pear (Opuntia ficus-barbarica A Berger) fruits. Food Chem. 2020. https://doi.org/10.1016/j.foodchem.2019.125387.

Kahramanoğlu İ. Effects of lemongrass oil application and modified atmosphere packaging on the postharvest life and quality of strawberry fruits. Sci Hort. 2019. https://doi.org/10.1016/j.scienta.2019.05.054.

Kahramanoğlu i. Preserving postharvest storage quality of fresh loquat fruits by using different bio-materials. J Food Sci Technol. 2020. https://doi. org/10.1007/s13197-020-04333-5.

Kahramanoğlu I, Chen C, Chen J, Wan C. Chemical constituents, antimicrobial activity, and food preservative characteristics of Aloe vera Gel. Agronomy. 2019. https://doi.org/10.3390/agronomy9120831.

Kator L, Hosea ZY, Ene OP. The Efficacy of Aloe-vera coating on postharvest shelf life and quality tomato fruits during storage. Asian Res J Agric. 2018. https://doi.org/10.9734/ARJA/2018/41540.

Kuwar U, Sharma S, Tadapaneni VRR. Aloe Vera gel and honey-based edible coatings combined with chemical dip as a safe means for quality maintenance and shelf life extension of fresh-cut papaya. J Food Quality. 2015. https://doi.org/10.1111/jfq.12150.

Li X, Li M, Wang L, Wang J, Jin P, Zheng Y. Methyl jasmonate primes defense responses against wounding stress and enhances phenolic accumulation in fresh-cut pitaya fruit. Postharvest Biol Technol. 2018. https://doi. org/10.1016/j.postharvbio.2018.07.001.

Márquez-Berber SR, Torcuato-Calderón C, Almaguer-Vargas G, Colinas-León MT, Gardezi AK. Cactus pear (Opuntia albicarpa and O. megacantha) production system in Axapusco, Estado de México Problems and alternatives. Rev Chap Ser Hortic. 2012. https://doi.org/10.5154/r.rchsh 2012.18.006

Martínez-Romero D, Alburquerque N, Valverde JM, Guillien F, Castillo S, Valero $D$, Serrano M. Postharvest sweet cherry quality and safety maintenance by Aloe vera treatment: a new edible coating. Postharvest Biol Technol. 2006. https://doi.org/10.1016/j.postharvbio.2005.09.006.

Martínez-Romero D, Castillo S, Guillén F, Díaz-Mula HM, Zapata PJ, Valeroa D, Serranoba M. Aloe vera gel coating maintains quality and safety of readyto-eatpomegranate arils. Postharvest Biol Technol. 2013. https://doi. org/10.1016/j.postharvbio.2013.06.022.

Mellinas C, Valdés A, Ramos M, Burgos N, Del Carmen Garrigós M, Jiménez A. Active edible films: current state and future trends. J Appl Polym Sci. 2016. https://doi.org/10.1002/app.42631.

Mendy T, Misran A, Mahmud T, Ismail S. Antifungal properties of Aloe vera through in vitro and in vivo screening against postharvest pathogens of papaya fruit. Sci Hortic. 2019. https://doi.org/10.1016/j.scienta.2019.10876 7. 
Mohebbi M, Hasanpour N, Ansarifar E, Amiryousefi MR. Physicochemical properties of bell pepper and kinetics of its color change influenced by Aloe vera and gum tragacanth coatings during storage at different temperatures. J Food Process Preserv. 2014. https://doi.org/10.1111/jfpp.12018.

Ochoa-Velasco CE, Guerrero-Beltrán JA. The effects of modified atmospheres on prickly pear (Opuntia albicarpa) stored at different temperatures. Postharvest Biol Technol. 2016. https://doi.org/10.1016/j.postharvbi 0.2015 .09 .028

Orhan DD, Orhan N, Özçelik B, Ergün F. Biological activities of Vitis vinifera L. leaves. Turk J Biol. 2009. https://doi.org/10.3906/biy-0806-17.

Ortiz-Zarama MA, Jiménez-Aparicio AR, Solorza-Feria J. Obtainment and partial characterization of biodegradable gelatin films with tannic acid, bentonite and glycerol. J Sci Food Agric. 2016;96:3424-31.

Parven A, Sarker MR, Megharaj M, Meftaul IM. Prolonging the shelf life of Papaya (Carica papaya L.) using Aloe vera gel at ambient temperature. Sci Hortic. 2020. https://doi.org/10.1016/j.scienta.2020.109228.

Piga A, Aquino SD, Agabbio M, Emonti G, Farris GA. Influence of storage temperature on shelf-life of minimally processed cactus pear fruits. LWT. 2000. https://doi.org/10.1006/fstl.1999.0604.

Piga A, Del Caro A, Pinna I, Agabbio M. Changes in ascorbicacid, polyphenol content and antioxidant activity in minimallyprocessed cactus pear fruits. Food Sci Technol. 2003. https://doi.org/10.1016/S0023-6438(02)00227-X.

Pintaća D, Četojević-Simin D, Berežnia S, Orčića D, Mimica-Dukića N, Lesjak M. Investigation of the chemical composition and biological activity of edible grapevine (Vitis vinifera L.) leaf varieties. Food Chem. 2019. https:// doi.org/10.1016/j.foodchem.2019.02.049.

Radi M, Firouzi E, Akhavan H, Amiri S. Effect of gelatin-based edible coatings incorporated with Aloe vera and black and green tea extracts on the shelf life of fresh-cut oranges. J Food Qaul. 2017. https://doi. org/10.1155/2017/9764650.

Ragaert P, Jaccxsens L, Vandekinderen I, Baert L, Devlieghere F. Microbial and safety aspects of fresh-cut fruits and vegetables. In: Martín-Belloso O, Soliva-Fortuny RC, editors. Advances in fresh-cut fruit and vegetables processing. Boca Raton: CRC Press; 2011.

Rasouli M, Saba MK, Ramezanian A. Inhibitory effect of salicylic acid and Aloe vera gel edible coating on microbial load and chilling injury of orange fruit. Sci Hortic. 2019. https://doi.org/10.1016/j.scienta.2018.12.004.

Sharma RR, Singh D, Singh R. Biological control of postharvest diseases of fruits and vegetables by microbial antagonists: a review. Biol Cont. 2009. https ://doi.org/10.1016/j.biocontrol.2009.05.001.

Silvestre C, Duraccio D, Cimmino S. Food packaging based on polymer nanomaterials. Prog Polym Sci. 2011. https://doi.org/10.1016/j.progpolyms ci.2011.02.003.
Sogvar OB, Saba MK, Emamifar A. Aloe vera and ascorbic acid coatings maintain postharvest quality and reduce microbial load of strawberry fruit. Postharvest Biol Tech. 2016. https://doi.org/10.1016/j.postharvbi 0.2015.11.019.

Song HY, Jo WS, Song NB, Min SC, Song KB. Quality change of apple slices coated with Aloe vera gel during storage. J Food Sci. 2013. https://doi. org/10.1111/1750-3841.12141.

Sophia O, Robert GM, Ngwela WJ. Effect of Aloe vera gel coating on postharvest quality and shelf life of mango (Magnifera indica L.) fruits var. 'Ngowe' J Hort For. 2015. https://doi.org/10.5897/jhf2014.0370.

Supapvanich S, Mitrsang P, Srinorkham P, Boonyaritthongchai P, Wongs-Aree C. Effects of fresh Aloe vera gel coating on browning alleviation of fresh cut wax apple (Syzygium samarangenese) fruit cv. Taaptimjaan. J Food Sci Technol. 2016. https://doi.org/10.1007/s13197-016-2262-4.

Tesfahun W. Climate change mitigation and adaptation through biotechnology approaches: a review. Int J Agric For Life Sci. 2018;2(1):62-74.

Tesoriere L, Butera D, Pintaudi AM, Allegra M, Livrea MA. Supplementation with cactus pear (Opuntia ficus-indica) fruitsdecreases oxidative stress in healthy humans. A comparative study with vitamin C. Am J Clin Nutr. 2004. https://doi.org/10.1093/ajcn/80.2.391.

Timpanaro G, Foti VT. The structural characteristics, economic performance and prospects for the Italian cactus pear industry. J Prof Assoc Cactus Devel. 2014;16:32-50.

Troyo R, Acedo A. Effects of calcium ascorbate and calcium lactate on quality of fresh-cut pineapple (Ananas comosus). Int J Agric For Life Sci. 2019;3(1):143-50.

Whitaker JR, Lee CY. Recent advances in chemistry of enzymatic browning. An overview. In: Lee CY, Whitaker JR, editors. Enzymatic browning and its prevention. ACS symposium series 1995;600:1-7.

Zhou Y-X, Xin H-L, Rahman K, Wang S-J, Peng C, Zhang H. Portulaca oleracea L.: a review of phytochemistry and pharmacological effects. Biomed Res Int. 2015; 925631.

Zudaire L, Viñas I, Lafarga T, Plaza L, Echevarria G, Gloria BOBO, Altisent R, Aguiló-Aguayo I. Effect of calcium salts and antioxidant treatment on the storage quality of fresh-cut Conference pears. Int J Agric For Life Sci. 2019;3(2):331-44.

\section{Publisher's Note}

Springer Nature remains neutral with regard to jurisdictional claims in published maps and institutional affiliations.
Ready to submit your research? Choose BMC and benefit from:

- fast, convenient online submission

- thorough peer review by experienced researchers in your field

- rapid publication on acceptance

- support for research data, including large and complex data types

- gold Open Access which fosters wider collaboration and increased citations

- maximum visibility for your research: over 100M website views per year

At BMC, research is always in progress.

Learn more biomedcentral.com/submissions 